\title{
Capital and Liquidity Risks and Financial Stability: Pre, During and Post Financial Crisis Between Islamic and Conventional Banks in GCC Countries, in the Light of Oil Prices Decline
}

\author{
Hamid Abdulkhaleq Hasan Al-Wesabi ${ }^{1} \&$ Rosylin Mohd. Yusof ${ }^{1}$ \\ ${ }^{1}$ Islamic Business School (IBS), University Utara Malaysia, Sintok, Kedah, Malaysia \\ Correspondence: Hamid Abdulkhaleq Hasan Al-Wesabi, Islamic Business School (IBS), University Utara Malaysia, \\ Sintok, Kedah, Malaysia.
}

Received: October 11, 2019

Accepted: November 16, 2019

Online Published: November 26, 2019

doi:10.5430/ijfr.v11n1p329

URL: https://doi.org/10.5430/ijfr.v11n1p329

\begin{abstract}
Purpose: The main purpose of this paper is to investigate the impact of capital ratio and liquidity risks and the effects of the Global Financial Crisis (GFC) periods on financial stability of conventional and Islamic banks before, during, and after GFC in the year of 2008 five GCC countries. To examine empirically the comparison between conventional and Islamic banks based on financial stability and soundness, as well as capitalization and liquidity in the light of the adverse effects of GFC and oil prices declining during the period of (2000-2017).

Design/methodology/approach: By using time series data, this study employs Pedroni's panel cointegration analysis to test the long run relationship between financial stability of conventional banks and Islamic banks as a dependent variable and independent variables including financial crisis under three periods; pre (2006-2007), during (2008-2009) and post (2010-2011) crisis. As well as employing Generalized Least Squares (GLS) to examine the effects between independent variables which are GDP, inflation, financial crisis periods, oil prices fluctuations risk, banking competition, financial sector development, liquidity risk and capital adequacy ratio and dependent variable which is financial stability of conventional and Islamic banks in GCC countries before (2000-2006) during (2006-2009) and after (2010-2017) crisis.

Findings: The findings of this research suggest that there is a long run relationship between financial stability of conventional and Islamic banks and capital ratios, liquidity risk and other independent variables. As well as study's findings support some previous studies and it generally concludes that Islamic banks were performed better during the crisis than conventional banks. Whereas Islamic banks were more stable during crisis as their business model helped to limit the adverse effects of crisis in 2008 , they were also more capitalized and less exposure to liquidity risk. Nevertheless, decrease in Islamic banks' liquidity led some Islamic banks in GCC countries to declare significant losses in 2009.

Originality/value: The result of the study contributes towards understanding the determinants of financial stability of both Islamic banks and conventional banks during financial crisis periods. It is important for policy ramifications by the Central Banks in GCC in terms of treating both types of banks differently to mitigate against future financial crises.
\end{abstract}

Keywords: financial stability, global financial crisis, pedroni's panel cointegration test, Generalized Least Squares (GLS), GCC countries

\section{Introduction}

Financial stability of an institution in a financial system of a country has become a challenge in light of significant changes in the entire economy, the financial system and within the institution itself. The concept of 'financial stability' generally came about in the last decade to indicate the importance of the main functions of financial authorities led by Central Banks (Allen \& Wood, 2006). Banks' stability - whether Islamic banks (IBs henceforth) or conventional banks (CBs henceforth) - has been defined by Miah, M. D., and Uddin, H. (2017). However, the best is to define financial stability of banks as the period when the instability of banks is absence (Allen \& Wood, 2006). However, Iqbal, Mirakhor, Krichenne, and Askari (2010) opined that financial stability is an accounting concept, representing the concept of solvency or equilibrium. It means that financial stability is described by the position of 
the liquid treasury, which shows whether the use of funds exceeds the sources of funds to be covered internally at abnormal times or during financial crises.

The global financial crisis is a lesson for bankers to be more cautious in the future, as no bank was immune to this crisis. During the financial crisis (2008/2009), many CBs suffered bank runs and announced bankruptcy, but no Islamic bank went bankrupt (Ghassan, Fachin, \& Guendoz, 2012). Nevertheless, that does not mean that IBs are immune to financial crises; they are affected, even indirectly influenced by the causes of the financial crises. One of these causes was the fall in oil prices, which mainly affected IBs banks in the Gulf Cooperation Council (GCC) (Zarrouk, 2012). Thus, this paper attempts to explore the impact of the Global Financial Crisis (GFC) through three periods, which are pre (2006-2007), during (2008-2009), and post (2010-2011) crisis. Then compare the impact of the three crisis periods between conventional and Islamic bank stability in GCC countries in the long run.

GCC countries are chosen because they have a dual banking system, and the presence of IBs in GCC countries became more prominent, with more than $25 \%$ market share out of all GCC Banks' total assets. For example, IBs in all Middle East and North Africa (MENA) countries have only 14\% market share out of all total assets of MENA banks (Basu, Prasad, \& Rodriguez, 2015). Given the prominence of Islamic banking presence in the GCC counties and operating in parallel with their conventional counterparts, it is therefore imperative to assess whether IBs are sound and more stable than CBs within the three periods or the opposite. Understanding the impact of GFC and the comparison between IBs and CBs within the three periods will help the Central Banks to design policies to affect IBs and CBs differently to mitigate financial risks against future financial crises. That would be the first motivation of this study, and the second is to clarify the importance of banking institutions to the economy as banks play the primary role in financial intermediation which is to allocate surplus funds or deposits from surplus units, savers or lenders, then effectively and efficiently support deficit units, borrowers or investors. That could be allocated physical capital in the economy in order to run the projects and enhance business development and trade in the economy and financial system (Allen \& Carletti, 2008). However, the Islamic bank has an essential difference from the conventional bank that is the prohibition of interest on loans and deposits because Islamic bank follows the principals of Islamic law (sharia). This difference may reflect on the stability of each type of bank to affect the stability of another type.

\section{Literature Review}

Empirical studies conducted on individual bank's stability focus more on the impact of financial stability or its financial soundness. For example, these studies highlighted the comparison between the financial stability of IBs and CBs and also the stability of larger and smaller banks. However, a few studies used three periods pre, during and post GFC, then comparing between IBs and CBs in terms of their financial stability and financial soundness. Also, there is no consensus on whether IBs or CBs more stable than each other (Ghassan \& Fachin, 2016). So, clarifying the differences between IBs and CBs in terms of financial stability is still limited. Also, the feature of this current study is to analyze each type of bank separately and not to divide banks into small and large as it was done by most of the studies in this field. This study adopts IBs and CBs stability as the dependent variable (measured by Z-score index) and the independent variables as determinants of bank's stability. Hence, independent variables have chosen as the most relevant to bank's stability as influenced substantially by the adverse effects of GFC, those variables are growth of Gross Domestic Product (GDP), inflation rate, financial crisis period, oil price fluctuations risk, banking competition, financial sector development, liquidity risk, and capital adequacy ratio.

By reviewing the literature of financial stability, most of these studies have also provided evidences that financial stability is adversely affected by the GFC with varying impacts across countries and periods for both CBs and IBs (Fu, Lin, \& Molyneux, 2014; Ghosh, 2014). For example, IBs were better capitalized with higher ratios of asset quality and more cost-effective (Beck et al., 2013). Furthermore, Beck et al. (2013) also assert that profit-loss sharing (PLS) modes that are adopted by IBs make them more resilient against this crisis than CBs (Abduh, Omar, \& Duasa, 2011). However, some studies, such as Bourkhis and Nabi (2013) indicated that there is no significant difference in the stability of CBs and IBs, which are affected similarly due to GFC.

However, Hasan and Dridi (2011) found that IBs performed better in terms of performance compared to the CBs during the financial crisis, and thus they were contributing to financial stability. Meanwhile, Gamaginta and Rokhim (2009) found that IBs are less stable than CBs. However, it is also found that IBs are better capitalized with higher intermediation ratio and higher asset quality, even though they are less cost-effective than the CBs, which perhaps make IBs better stock performance during financial crisis 2008/2009 (Beck, Demirguc-Kunt, \& Merrouche, 2013). As well as, during the crisis, IBs withstood better than CBs as not a single Islamic bank was declared bankrupt unlike the CBs (Ghassan, Fachin, \& Guendoz, 2013). Notwithstanding the above success story of IBs, the IBs are also 
found to not insulated against the adverse impact of that crisis as they could also be affected by the indirect impacts of the crises (Ali, 2012).

Nevertheless, studies of bank's stability used to divide each type of bank based on its size into small and large banks. For instance, Čihák and Hesse $(2008 ; 2010)$ opined that the size of the bank must be considered, in order to perform a comparison between the stability of IBs and that of the conventional ones. Čihák and Hesse $(2008 ; 2010)$ further found that large IBs are riskier than small IBs where they are more stable than their counterparts from CBs. It is also supported by the studies of Shahid and Abbas (2012), and Abedifar, Molyneux, and Tarazi (2013), which assert that large IBs are riskier than small ones where they are more stable than large CBs. As well, large CBs are riskier than the small ones, these also the same findings of Shahid and Abbas (2012), and Abedifar, Molyneux, and Tarazi (2013). Hence, heterogeneity across banks matters more than the nature of the bank, whether Islamic or conventional. So, this study uses Pedroni's (1999, 2004), which is a feature that may solve the need to divide banks into small and large banks to examine their degree of financial stability during the adverse effect of GFC on IBs or CBs.

Some studies acknowledged the on-going debate comparing the stability of both CBs and IBs. Furthermore, this current paper attempts to go beyond this debate to examine which type of bank is more stable pre, during, and post GFC, IBs or CBs. In doing so, three categories of variables have been chosen to examine the stability by comparing between IBs and CBs pre, during, and post GFC. Macroeconomic variables are four variables, including financial crisis periods which were selected as dummies variables took one for years pre (2006-2007), during (2008-2009), or post-crisis (2010-2011) and zero otherwise. This study also applied the analysis of each period; before the crisis (2000-2006), crisis period (2007-2009), and after crisis (2010-2017) (Adelopo, Lloydking, Tauringana, \& Lloydking, 2018). Including macroeconomic variables, GDP, inflation rate and oil prices fluctuations risk as an essential variable in the GCC countries. Then the relevant variables of the banking industry category, which are banking competition, financial sector development and specific to bank variables: liquidity risk and capital adequacy ratio.

Macroeconomic factors play a crucial role in triggering banking crises, which occur due to an interaction between macroeconomic and financial factors and bank's structural weaknesses. Macroeconomic factors impact banks through many adverse conditions, such as levels of negative growth, high rates of banking interest, high rate of inflation and high level of unemployment (Castro, 2013). According to many studies, the key macroeconomic factors include real GDP growth, inflation rate, real interest rate and nominal exchange rate changes (Ree, 2011); GDP growth, inflation rate and LIBOR (Al-Wesabi \& Ahmad, 2013); and GDP growth, GDP per capita, current account and interest rate (Bicaba et al., 2014). Most of the studies have selected the growth of GDP and rate of inflation (INFR) as important macroeconomic variables to be regressed to test their variability relative to financial stability.

GDP in GCC countries is the most common indicator used to measure total economic activities from a macroeconomic perspective, which affects banks' performance through demand and supply of deposits and loans (Sufian \& Habibullah, 2009). GDP growth tends to have a significant and positive relationship with bank stability as found in a majority of studies. Inflation rate may also have a direct and indirect impact on the bank performance through increased price of labour and changes in prices of assets, respectively (Sufian \& Habibullah, 2009). Thus, it is expected that Inflation rate has a negative relationship related to stability of banks (Srairi, 2013). Nonetheless, some researchers have found the opposite result, where GDP growth is negatively related to bank stability; the inflation rate is positively related to bank stability (Ghenimi \& Omri, 2015a).

Fluctuations in oil prices in GCC countries are one of the essential factors that could influence banks' financial soundness. As reported by the team of the International Monetary Fund (IMF, 2015) that there is a link between economic growth and revenues of oil exports. That means that a rise in oil price leads to higher government expenditure and a stronger fiscal position, which in turn leads to a rise in corporate profitability and strengthen the balance sheets of banks (Callen, Khandelwal, Miyajima, \& Santos, 2015). Accordingly, the drop in oil revenues could be a significant risk that determines credit default, which harms banks' solvency and adversely affects the real economy (Khandelwal, Miyajima, \& Santos, 2016). So, financial soundness is more affected by oil price shocks compared to the impact of just an increase in oil price. As in general financial performance is linked to oil price fluctuations in oil-rich economies, such as in GCC countries (Al-Khazali \& Mirzaei, 2017). It is therefore imperative that these countries, like the ones in GCC to be more diversified in terms of managing their economies rather than depending on just on oil sector revenues (Mehrara, 2008).

From the industry-specific of the banking system, the degree of competition among banks is considered by this current study as an essential determinant of bank fragility and generally measured by concentration ratio (Note 1) (Al-Khouri \& Arouri, 2016). One of the most common measures used to measure banking concentration is the Herfindahl-Hirschman index (Note 2) (HHI), which ranges from 0 (i.e., zero is represented minimum concentration 
or maximum competition) to 10,000 (i.e., 10,000 is represented maximum concentration or minimum competition). HHI is found to be significantly and negatively related to financial stability, therefore, the higher the banking concentration, the lesser will be the competition, and the lower will be the degree of financial stability (Čihák \& Hesse, 2010; Ghassan et al., 2013).

In addition to the development of financial sector as another variable represents the banking industry, and it may enhance bank efficiency and performance in some less developed countries. However, results from other studies indicated otherwise. For instance, these studies allude that more significant development of financial sector could also create more competition, which may adversely impact the profitability of banks (Growe, DeBruine, Lee, \& Maldonado, 2014). Financial sector development is measured by the ratio of bank credit to the private sector divided by GDP (Bongini, Iwanicz-Drozdowska, Smaga, \& Witkowski, 2017).

Liquidity risk and capital ratio are represented for the banks' specific financial risks. As we will notice in the next section that the Z-score equation includes capital and profits as banks' buffers and financial risk (Degl'Innocenti, Grant, Šević, \& Tzeremes, 2018). So, in order to reduce the risk related to assets, one of strategies is to increase capital buffer and assets' liquidity according to the say "the greater the liquidity of the bank's assets, the lower is the risk of assets and, thus, the greater the capital buffer" (de Mendonça \& de Moraes, 2018). Initially, and according to many studies, there is a positive relationship between bank stability and capital ratio (Ashraf, Arshad, \& Hu, 2016; Bitar, 2013; Ghenimi, Chaibi, \& Omri, 2017; Ghenimi \& Omri, 2015a; Ghosh, 2014). However, capital ratio turned to be negative or positive such impact depends on the long-run capital ratio's target whether deficit tends (positive effect) or surplus tends (negative effect) (Osborne, Fuertes, \& Milne, 2012). So, capital and liquidity must fulfill the requirements of organizations' regulations, such as under Basel III. Thus these regulations help in increasing the bank's resilience, which is, in turn, absorb shocks, such as oil prices decline (Klingelhöfer \& Sun, 2019). It is also reported that low liquidity has a significant and negative effect on bank compliance to rule and regulations that have proposed by Basel III. So, the bank would comply less to hold high ratio of capital as required, once attract more deposits and grant more loans, which means more illiquid assets (Abdelbadie \& Salama, 2019).

\subsection{Financial Stability Measure}

Generally, financial stability of a bank is defined as the period of bank instability absence (Allen \& Wood, 2006). As indicated, the financial instability of banks could be due to insolvency risk that can be hurt the economy as what happened during financial crises (Fethi \& Pasiouras, 2010). Therefore, the absence of banks' instability was reported during the GFC as some of the CBs went bankrupt (Ghassan et al., 2013), and CBs suffer a substantial decline in profitability due to failure to manage financial risks during GFC (Hasan \& Dridi, 2011).

Stability of IBs and CBs measured by the Z-score index, (ROA plus ratio of capital (or TE=total equity to total asset (TA), divided by standard deviation of ROA) as a common measure used by many studies (Beck et al., 2013; M. Čihák \& Hesse, 2008; Martin Čihák \& Hesse, 2010; Fu et al., 2014; Ghassan et al., 2013; Ghosh, 2014). Nevertheless, the recent study of Clark et al. (2018) who have used a new approach of the Z-score formula (as shown in 1 and the appendix of summary of all variables' measures, data resources and related references are shown) which is produced by Mare et al. (2017). Mare et al. (2017) criticized all previous approaches of Z-score index as they are deemed to be less effective. Against this backdrop, this paper will follow Clark et al. (2018), who adopted the following formula:

$$
Z_{i, t}=\frac{\mu_{R O A, t}+T E / T A_{i, T}}{\sigma_{R O A, t}} \text { with } t \in\{1,2, \ldots, T\}
$$

Where: $\mu_{R O A, t}$ : the moving mean ROA, period t: the current period. As noticed, Z-score includes from one hand, capital and profits, which are banks' buffers, and on the other hand, financial risk, which is measured through the denominator of formula 1 , which is standard deviation of ROA. Thus, more stability is achieved by a higher Z-score value, which in turn indicates a lower probability of insolvency risk (Degl'Innocenti et al., 2018).

This measurement will be applied for the stability of IBs and CBs separately, and then the comparison between the two types of banks will depend on the result of each type of bank to check which type is more stable and financially more strengthen during GFC. Many of researches that studied the comparison between IBs and CBs and examined which type is more profitable and more capitalized (Alturai \& Ki, 2013; Siraj \& Pillai, 2012; Toumi, Viviani, \& Belkacem, 2011; Youssef \& Samir, 2015). Thus, this present paper seeks also to examine the effects of GFC on IBs and CBs' stability empirically (Z-score index of IBs (ZSC_IB) and Z-score index of CBs (ZSC_CB)). 
Existing literature also alluded that the type of banks, i.e. whether Islamic or conventional does not matter in terms of financial stability, which matters is the size of banks, as there is individual heterogeneity across banks due to difference in bank size. So, the total asset of a bank is used by some studies to categorize banks into large and small banks, as bank size has different effects on bank stability (Martin Čihák \& Hesse, 2010; Distinguin, Roulet, \& Tarazi, 2013; Ghassan et al., 2013). Therefore, this research also attempts to investigate whether the nature of the bank (Islamic or conventional) matters in order to capture the impact of GFC on financial stability of IBs and CBs, as well as it examines if heterogeneity across banks (in terms of their total assists) matters more than Islamic or conventional nature of the banks. Hence, understanding the nature of the relationship between macroeconomic variables, industry-specific variables and specific to bank variables is essential to mitigate instability of both IBs and CBs and maintain bank stable against future crises.

\section{Data and Methodology}

\subsection{Theoretical Framework}

As mentioned above that the purpose of this research is to investigate the GFC periods (pre, during and post-crisis) effects on financial stability of IBs and CBs. As well as to check whether the nature of the bank (Islamic or conventional) matters in order to capture the impact of GFC periods on financial stability of IBs and CBs in the long run. Besides, this current paper seeks to examine whether heterogeneity across banks matters for Islamic and conventional nature of the bank. Therefore, an analysis of panel cointegration following Pedroni's $(1999,2004)$ method will be employed to allow for heterogeneity using coefficients of the cointegration equation.

As shown in Figure 1 and equations (2) and (3), this research has taken into consideration four macroeconomic variables such as GFC Periods (GFCPs), growth of Gross Domestic Product (GDPG), inflation rate (INFR) and Oil Prices movements Risk (OPR). Moreover, two other variables from the banking industry-specific as bank competition (HHI) and financial sector development (FSD), that could have an impact on stability of IBs. In addition to liquidity risk (LR) and capital adequacy ratio (CAR), which are specific to bank variables and represent the essential financial risks relevant to financial stability. Data has been collected from the GCC region, from banking industry of each country, and individual banks, whether IBs or CBs.

To analyze the relationship between GFC periods and financial stability of IBs and CBs and other independent variables, on one hand, this study follow Adelopo et al., (2018) to use the analysis for each period such as before crisis (2000-2006), during crisis (2007-2009) and after crisis (2010-2017). On the other hand, we also used GFC periods' dummies for pre (2006-2007), during (2008-2009), and post (2010-2011). Balanced panel data have been collected from the data stream and bank scope data base for 62 banks (19 IBs and 43 CBs). Data sample from 2000 to 2017 for five GCC countries excluded Oman, which entered to the Islamic banking industry just in 2012. So, function 2 expresses this relation, and the panel model 3 explains the regression equation:

$$
Z S C=f(G F C P, G D P G, I N F R, O P R, H H I, F S D, L R, C A R)
$$

\begin{tabular}{|c|c|}
\hline Independent Variables & Dependent Variables \\
\hline GFCPs & \multirow{8}{*}{$\mathrm{ZSC}$} \\
\hline GDPG & \\
\hline INFR & \\
\hline OPR & \\
\hline HHI & \\
\hline FSD & \\
\hline LR & \\
\hline CAR & \\
\hline
\end{tabular}

Figure 1. Theoretical framework

And the model is:

$$
Z S C_{i t}=\beta_{0 i}+\beta_{1 \mathrm{i}} G F C P_{i t}+\beta_{2 \mathrm{i}} G D P G_{i t}+\beta_{3 \mathrm{i}} I N F R_{i t}+\beta_{4 i} O P R_{i t}+\beta_{5 i} H H I_{i t}
$$




$$
+\beta_{6 i} F S D_{i t}+\beta_{5 i} L R_{i t}+\beta_{6 i} C A R_{i t}+\varepsilon_{i t}
$$

Where: $Z S C_{i t}$ is Z-score index for Islamic and conventional bank (i) in year (t),

$\beta_{0 i}$ : Constant coefficient,

$\beta_{\mathrm{ni}}=$ The slope coefficient and $1 \ldots \mathrm{n}$ : number of the variable,

$G F C P_{i t}$ : Global financial crisis period for the country (i) in year (t),

$G D P G_{i t}$ : Gross domestic product growth for the country (i) in year (t),

$I N F R_{i t}$ : Inflation rate for the country (i) in year ( $\mathrm{t}$ ),

$O P R_{i t}$ : Oil prices risk exposure for the country (i) in year ( $\mathrm{t}$ ),

$H H I_{i t}$ : Banks concentration for the banking system of the country (i) in year (t),

$F S D_{i t}$ : Financial sector development for the banking system of the country (i) in year ( $\mathrm{t}$ ),

$L R_{i t}$ : Liquidity risk for bank (i) in year ( $\mathrm{t}$ ),

$C A R_{i t}$ : capital adequacy ratio for bank (i) in year (t), and

$\varepsilon_{i t}$ : Term of the random error.

\subsection{The Panel Unit Root Test}

We start our analysis to test the presence of unit root (data stationarity) of each variable in time series data. It is essential to test the order of the series or presence of unit root in the series in order to get an appropriate panel model (Musibau, Yusuf, \& Gold, 2019). Whereas, there are several tests usually used for this purpose, such as Levin and Lin (1993), Hadri (2000), Levin, Lin and Chu (LLC) (2002) and Im, Pesaran, and Shin (1997, 2003). Thus, this paper used the most common tests such as Levin et al. (LLC) (2002) and Im, Pesaran, and Shin $(1997,2003)$ as also considered the two recent unit root tests (Annala \& Chen, 2011). According to Musibau et al. (2019), the main hypothesis of panel unit root as established in LLC is as shown in equation (4).

$$
\Delta Y_{t}=\alpha+\lambda t+\gamma Y_{t-1}+\sum_{i=1}^{k} \beta_{i} \Delta Y_{t-i}+\varepsilon_{t}
$$

The variable $Y_{t}$ represents each variable included in this research. In addition to the importance of checking the presence of unit root in time series data, the Pedroni's panel cointegration is also useful to solve the heterogeneity issues and to control the bias of country size (Syed Ali, 2017). In order to examine stationarity of data using unit root tests, the above tests will be implemented using confidence level of $5 \%$ to examine null and alternative hypotheses as follows:

H0: Data are non-stationary (or it has a unit root)

H1: Data are stationary (or it has no unit root)

\subsection{The Panel Cointegration Test}

Two groups of tests for panel cointegration were recommended by Pedroni $(1999,2004)$. First, panel tests within dimension based and include four statistics (Note 3), which essentially pool the coefficients of autoregressive and consider the heterogeneity across banks and common time factors. Second, tests based on the between dimension approach, which include three groups of statistics (Note 4), which are based on averages of individual autoregressive coefficients associated with the tests of data stationarity or unit root of the residual for each bank in the panel of time series. Pedroni (2004) documented an approach that can overcome the problem of implementing panel data with small samples while allowing heterogeneity for slopes $\left(\beta_{n}\right)$ and intercepts $\left(\beta_{0}\right)$ of the equation of cointegration (Mohd. Yusof \& Bahlous, 2013; Sapuan, 2013). The seven tests of Pedroni are based on residuals that estimated as shown in the long run model (5) as follows:

$$
y_{i t}=\alpha_{i}+\sum_{j=1}^{m} \beta_{j i} x_{j i t}+\varepsilon_{i t}
$$

Where $\varepsilon_{i t}=\rho_{i} \varepsilon_{i(t-1)}+w_{i t}$ are the residuals that estimated from the panel regression. So, Pedroni $(1999,2004)$ will be employed by this research to incorporate the heterogeneity test of panel cointegration, which allows for 
cross-section effects of individual banks with heterogeneous intercept and slopes of cointegration equation to be tested, as well as to overcome the problem of the small sample.

\subsection{Generalized Least Squares (GLS)}

Despite the presence of long-run relationships that can be tested by using the method of Pedroni's panel cointegration, this method could not provide the estimation of coefficient (Shaukat, Hasan, \& Alhabshi, 2014). So, for the coefficients' estimation, a feasible generalized least squares (GLS) analysis is proposed because of the form of heteroskedasticity, which may be a misidentification. Thus, this paper used the GLS to test the relationships; such estimation is considered a more powerful test and its results more efficient than ordinary least squares (OLS). As well as to solve problems of serial correlation and heteroskedasticity (Baltagi \& Wu, 1999; Hansen, 2007; Miller \& Startz, 2018).

Finally, to test whether there is cointegration, we need to accept or to reject the null hypothesis of no cointegration, $\left(\mathrm{H}_{0}: \rho_{\mathrm{i}}=1\right.$ for all $\left.i\right)$ against the alternative of existence of cointegration, in the within-dimension $\left(\mathrm{H}_{\mathrm{A}}: \rho_{\mathrm{i}}=\rho<1\right.$ for all $i$ ) but for the between-dimension statistics $\left(\mathrm{H}_{\mathrm{A}}\right.$ : $\rho_{\mathrm{i}}<1$ for all $i$ ) (Fowowe, 2011). So, the two hypotheses are presented as $\mathrm{H}_{0}$ : No cointegration, and $H_{A}$ : Cointegration exists.

\section{Results}

\subsection{Panel Unit Root Tests}

Panel unit root tests are conducted for each variable as a requirement for panel cointegration. We start by running the tests of Levin et al. (LLC) (2002) and crucial, Pesaran, and Shin (1997, 2003) as the two recent and common unit root tests (Annala \& Chen, 2011). As shown in Tables 1 and 2 for CBs and IBs respectively, the test of data stationarity at level $\mathrm{I}(0)$ for variables of CBs and IBs, OPR has a unit root, as well as FSD has a unit root according to both LLC and IPS tests. Thus, unit root tests at first difference I(1) must be run to check data stationarity, which is required for analyzing using the panel cointegration test. As shown in Tables 3 and 4, tests of unite root results on the first differences I(1) for all variables of CBs IBs respectively are significant at the $1 \%$ level of significance, which is to reject the non-stationary hypothesis and accept the alternative hypothesis of variable has no unit root and data are stationary.

Table 1. Unit root tests (at level) - conventional banks

\begin{tabular}{llll}
\hline$H_{0}$ : variable have a unit root or variable is non-stationary & \\
\hline Variables & LLC & IPS & Decision \\
\hline ZSC & $-9.44541[0.0000]^{*}$ & $-9.76939[0.0000]^{*}$ & Reject $H_{0}$ \\
\hline GDPG & $-13.3883[0.0000]^{*}$ & $-9.11593[0.0000]^{*}$ & Reject $H_{0}$ \\
\hline INF & $-4.44606[0.0000]^{*}$ & $-3.74676[0.0001]^{*}$ & Reject $H_{0}$ \\
GFCP & No result & $-9.47061[0.0000]^{*}$ & Inconclusive \\
\hline OPRE & $-1.19675[0.1157]$ & $-0.14904[0.4408]^{*}$ & Do not reject $H_{0}$ \\
\hline HHI & $-14.3782[0.0000]^{*}$ & $-22.8856[0.0000]^{*}$ & Reject $H_{0}$ \\
\hline FSD & $-0.97986[0.1636]$ & $3.12821[0.9991]$ & Do not reject $H_{0}$ \\
\hline LIQR & $-11.3669[0.0000]^{*}$ & $-8.59147[0.0000]^{*}$ & Reject $H_{0}$ \\
\hline CAR & $-8.05756[0.0000]^{*}$ & $-7.15507[0.0000]^{*}$ & Reject $H_{0}$ \\
\hline
\end{tabular}

Note: * Indicate to the significance level at the $1 \%$

Table 2. Unit root tests (at level) - Islamic banks

\begin{tabular}{|c|c|c|c|}
\hline \multicolumn{4}{|c|}{$H_{0}$ : variable have a unit root or variable is non-stationary } \\
\hline Variables & LLC & IPS & Decision \\
\hline ZSC & $-2.65276[0.0040] *$ & $-5.16025[0.0000] *$ & Reject $H_{0}$ \\
\hline
\end{tabular}




\begin{tabular}{llllll}
\hline GDPG & -7.62675 & {$[0.0000]^{*}$} & -5.02392 & {$[0.0000]^{*}$} & Reject $H_{0}$ \\
\hline INF & -3.31593 & {$[0.0005]^{*}$} & -2.76086 & {$[0.0029]^{*}$} & Reject $H_{0}$ \\
GFCP & No result & & -6.29536 & {$[0.0000]^{*}$} & Inconclusive \\
\hline OPRE & -0.79551 & {$[0.2132]$} & -0.09907 & {$[0.4605]$} & Do not reject $H_{0}$ \\
\hline HHI & -6.57628 & {$[0.0000]^{*}$} & -15.3523 & {$[0.0000]^{*}$} & Reject $H_{0}$ \\
\hline FSD & -0.21481 & {$[0.4150]$} & 2.58361 & {$[0.9951]$} & Do not reject $H_{0}$ \\
\hline LIQR & -6.34983 & {$[0.0000]^{*}$} & -5.48434 & {$[0.0000]^{*}$} & Reject $H_{0}$ \\
\hline CAR & -5.23587 & {$[0.0000]^{*}$} & -3.95422 & {$[0.0000]^{*}$} & Reject $H_{0}$ \\
\hline
\end{tabular}

Note: * Indicate to the significance level at the $1 \%$

Table 3. Unit root tests (at first difference) - conventional banks

\begin{tabular}{llllll}
\hline \multicolumn{6}{l}{$H_{0}$ : variable have a unit root or variable is non-stationary } \\
\hline Variables & LLC & \multicolumn{5}{l}{ IPS } & Decision \\
\hline ZSC & -22.6064 & {$[0.0000]^{*}$} & -21.5088 & {$[0.0000]^{*}$} & Reject $H_{0}$ \\
\hline GDPG & -28.9739 & {$[0.0000]^{*}$} & -24.5786 & {$[0.0000]^{*}$} & Reject $H_{0}$ \\
\hline INF & -24.3557 & {$[0.0000]^{*}$} & -18.2778 & {$[0.0001]^{*}$} & Reject $H_{0}$ \\
GFCP & -23.9637 & {$[0.0000]^{*}$} & -17.867 & {$[0.0000]^{*}$} & Reject $H_{0}$ \\
\hline OPRE & -19.6775 & {$[0.0000]^{*}$} & -12.9496 & {$[0.0000]^{*}$} & Reject $H_{0}$ \\
\hline HHI & -41.4168 & {$[0.0000]^{*}$} & -22.283 & {$[0.0000]^{*}$} & Reject $H_{0}$ \\
\hline FSD & -11.4399 & {$[0.0000]^{*}$} & -13.6613 & {$[0.0000]^{*}$} & Reject $H_{0}$ \\
\hline LIQR & -19.3617 & {$[0.0000]^{*}$} & -19.0829 & {$[0.0000]^{*}$} & Reject $H_{0}$ \\
\hline CAR & -19.9871 & {$[0.0000]^{*}$} & -16.2439 & {$[0.0000]^{*}$} & Reject $H_{0}$ \\
\hline
\end{tabular}

Note: * Indicate to the significance level at the $1 \%$

Table 4. Unit root tests (at first difference) - Islamic banks

\begin{tabular}{llllll}
\hline \multicolumn{7}{l}{$H_{0}$ : variable have a unit root or variable is non-stationary } \\
\hline Variables & LLC & \multicolumn{5}{l}{ IPS } & Decision \\
\hline ZSC & -11.9996 & {$[0.0000]^{*}$} & -12.4977 & {$[0.0000]^{*}$} & Reject $H_{0}$ \\
\hline GDPG & -20.3509 & {$[0.0000]^{*}$} & -16.986 & {$[0.0000]^{*}$} & Reject $H_{0}$ \\
\hline INF & -16.274 & {$[0.0000]^{*}$} & -12.1528 & {$[0.0001]^{*}$} & Reject $H_{0}$ \\
GFCP & -15.9293 & {$[0.0000]^{*}$} & -11.8767 & {$[0.0000]^{*}$} & Reject $H_{0}$ \\
\hline OPRE & -13.0801 & {$[0.0000]^{*}$} & -8.60793 & {$[0.0000]^{*}$} & Reject $H_{0}$ \\
\hline HHI & -32.1902 & {$[0.0000]^{*}$} & -17.5662 & {$[0.0000]^{*}$} & Reject $H_{0}$ \\
\hline FSD & -7.38385 & {$[0.0000]^{*}$} & -9.60299 & {$[0.0000]^{*}$} & Reject $H_{0}$ \\
\hline LIQR & -12.7726 & {$[0.0000]^{*}$} & -11.4223 & {$[0.0000]^{*}$} & Reject $H_{0}$ \\
\hline CAR & -12.9666 & {$[0.0000]^{*}$} & -10.412 & {$[0.0000]^{*}$} & Reject $H_{0}$
\end{tabular}

Note: * Indicate to the significance level at the $1 \%$

Hence, all variables are I(1), then Pedroni's panel cointegration tests are eligible to be used for examining the presence of a long-run relationship between financial stability of CBs and IBs as a dependent variable and mentioned independent variables. 


\subsection{Pedroni's Panel Cointegration Tests}

As shown in Tables 3 and 4, and according to Pedroni's tests based on three specifications: individual intercept, individual intercept and individual trend, and no intercept and trend for variables: ZSC of conventional (Table 3) and Islamic (Table 4) banks as a dependent variable and independent variables which are GDPG, GFCP, INF, OPRE HHI, FSD, LIQR and CAR. Variables are nine, which means it is not applicable to directly use panel Pedroni co-integration test, so firstly, it must apply Principal Component Analysis (PCA) of data, which is a statistical technique used for data reduction in Stata program. Then followed by the command "predict" to obtain the components themselves and reduce data to be a new column(s) of data, which is the index of the old columns of data (Jackson, 2003; Jolliffe, 2002).

This current study uses PCA and predicts commands for each category of variables to create the samilar data index with one column, thus, to reduce data to be applicable for Pedroni's panel cointegration tests. Therefore, based on this technique, this study creates a column for each category of variables. For example, the three categories: macroeconomic variables (MACRVAR) category, became one column as well as banking industry variables (INDVAR) and specific to bank variables (FRISKVAR). The result shows that the null hypothesis of no cointegration (at usually 0.05 level of significance) is rejected; instead, the alternative hypothesis of the presence of cointegration is accepted. So, there is a long-run relationship between variables that are described as cointegrated variables. That means financial stability of CBs and IBs is cointegrated with GDPG, GFCP, INF, OPR, HHI, FSD, LIQR, and CAR.

Table 5. Pedroni's panel cointegration tests - conventional banks

\begin{tabular}{lllllll}
\hline & Intercept & \multicolumn{3}{l}{ Intercept +Trend } & None \\
& Statistic & $\begin{array}{l}\text { Weighted } \\
\text { Statistic }\end{array}$ & Statistic & $\begin{array}{l}\text { Weighted } \\
\text { Statistic }\end{array}$ & Statistic & $\begin{array}{l}\text { Weighted } \\
\text { Statistic }\end{array}$ \\
\hline Panel v-Statistic & 0.7189 & -2.2951 & -2.5892 & -5.7134 & -2.5312 & -4.4233 \\
\hline Panel rho-Statistic & -0.1012 & -0.9091 & 2.7993 & 1.7144 & 0.8654 & 1.5170 \\
\hline Panel PP-Statistic & $-6.0030^{*}$ & $-10.2279^{*}$ & $-5.7700^{*}$ & $-12.4790^{*}$ & $-1.7775^{* *}$ & -0.8999 \\
\hline Panel ADF-Statistic & $-7.0650^{*}$ & $-10.1556^{*}$ & $-8.1883^{*}$ & $-11.6131^{*}$ & -1.0452 & -0.4991 \\
\hline Group rho-Statistic & 1.5787 & & 4.1069 & & 2.5920 & \\
\hline Group PP-Statistic & $-13.1962^{*}$ & & $-14.4457^{*}$ & & $-2.9581^{*}$ & \\
\hline Group ADF-Statistic & $-10.5952^{*}$ & & $-10.4757^{*}$ & & $-1.3061^{* * *}$ \\
\hline
\end{tabular}

Note: $* * *, * * *$ Significant at 1,5 and 10 percent levels, respectively

Table 6. Pedroni's panel cointegration tests - Islamic banks

\begin{tabular}{lllllll}
\hline & Intercept & \multicolumn{3}{l}{ Intercept +Trend } & None \\
& Statistic & $\begin{array}{l}\text { Weighted } \\
\text { Statistic }\end{array}$ & Statistic & $\begin{array}{l}\text { Weighted } \\
\text { Statistic }\end{array}$ & Statistic & $\begin{array}{l}\text { Weighted } \\
\text { Statistic }\end{array}$ \\
\hline Panel v-Statistic & 0.7012 & -1.2226 & -0.6614 & -3.1474 & -0.8063 & -2.3994 \\
\hline Panel rho-Statistic & 0.1421 & -0.1490 & 1.7604 & 1.3155 & 0.4960 & 0.6081 \\
\hline Panel PP-Statistic & $-5.1287^{*}$ & $-5.7850^{*}$ & $-5.3629^{*}$ & $-6.9259^{*}$ & $-1.4128^{* * *}$ & -0.9513 \\
\hline Panel ADF-Statistic & $-6.4480^{*}$ & $-6.7639^{*}$ & $-5.8974^{*}$ & $-7.9212^{*}$ & -0.6790 & -0.4348 \\
\hline Group rho-Statistic & 1.8283 & & 3.1729 & & 2.0592 & \\
\hline Group PP-Statistic & $-8.2062^{*}$ & & $-7.6228^{*}$ & & $-1.6916^{* *}$ & \\
\hline Group ADF-Statistic & $-7.9008^{*}$ & & $-6.4070^{*}$ & & 0.3001 & \\
\hline
\end{tabular}

Note: $* * *, * * *$ Significant at 1,5 and 10 percent levels, respectively

\subsection{GLS Estimations}


As mentioned, that GLS is proposed to be used by this research because of the presence of heteroskedastic case and the serial correlation in the data (Baltagi \& Wu, 1999; Miller \& Startz, 2018). As shown in Tables 7 and 9, the CBs and IBs heteroskedasticity tests, respectively are presented. As noticed that the null hypothesis of homoscedasticity is rejected, meaning that the heteroscedasticity is present in the data of both CBs and IBs. As well as the problem of serial correlation is existed in the data according to the results shown in Tables 8 and 10 results of CBs and IBs, respectively, for the serial correlation test. Since it fails to reject the null hypothesis of no serial correlation.

The results of the coefficients' estimation using GLS procedures are shown in Table 11 for data of CBs and IBs for pre-crisis (2006-2007 are used as dummies equal to one, and zero otherwise). It is found that the impact of GFC on the bank's stability pre-crisis is negative but not significant (0.982) for CBs and positive and not significant $(0.356)$ for IBs. Thus, there is a difference in impact pre-crisis between IBs and CBs; however, it is insignificant difference.

Table 12 shows the impact on the financial stability of IBs and CBs during the crisis and shows the difference between IBs and CBs during the crisis. As noticed, in terms of during crisis (2008-2009 are used as dummies equal to one, and zero otherwise), it is found that financial stability of CBs and IBs has a negative and significant impact during GFC (2008-2009). However, financial stability of CBs records higher values except at the end of the year 2008 which recorded lower than its counterparty of IBs, the significance level of Z-Score index of CBs is $0.01(0.010$ $=1 \%$ significance level $)$ is higher significance level than IBs' Z-Score index $(0.033<5 \%$ significance level $)$. That means the GFC's adverse impact (2008-2009) on CBs is more significant than its impact on IBs, which appeared to be more capitalized than CBs for all periods; pre, during and post-financial crisis.

Table 7. Heteroskedasticity test - conventional banks

\begin{tabular}{llll}
\hline \multicolumn{4}{l}{ Heteroskedasticity Test: White } \\
\hline F-statistic & 2.334331 & Prob. F (43,730) & $0.0000^{*}$ \\
\hline Obs R-squared & 93.56144 & Prob. Chi-Square (43) & $0.0000^{*}$ \\
\hline
\end{tabular}

Note: * Indicate to the significance level at the $1 \%$,

Table 8. Serial correlation LM test - conventional banks

\begin{tabular}{llll}
\hline \multicolumn{3}{l}{ Breusch-Godfrey Serial Correlation LM Test: } & \\
\hline F-statistic & 151.7097 & Prob. F $(2,763)$ & $0.0000^{*}$ \\
\hline Obs R-squared & 220.2198 & Prob. Chi-Square (2) & $0.0000^{*}$
\end{tabular}

Note: * Indicate to the significance level at the $1 \%$

Table 9. Heteroskedasticity test - Islamic banks

\begin{tabular}{llll}
\hline \multicolumn{4}{l}{ Heteroskedasticity Test: White } \\
\hline F-statistic & 3.677372 & Prob. F $(43,298)$ & $0.0000^{*}$ \\
\hline Obs R-squared & 118.5622 & Prob. Chi-Square (43) & $0.0000^{*}$ \\
\hline
\end{tabular}

Note: * Indicate to the significance level at the $1 \%$

Table 10. Serial correlation LM test- Islamic banks

\begin{tabular}{llll}
\hline \multicolumn{4}{l}{ Breusch-Godfrey Serial Correlation LM Test: } \\
\hline F-statistic & 158.5766 & Prob. F $(2,331)$ & $0.0000^{*}$ \\
\hline Obs R-squared & 167.3469 & Prob. Chi-Square (2) & $0.0000^{*}$ \\
\hline
\end{tabular}

Note: * Indicate to the significance level at the $1 \%$

Table 13 shows the periods of post-financial crisis 2010-2011 are used as dummies equal to one and zero otherwise). As noticed, the impact of GFC on the bank's stability post-crisis is negative but not significant for CBs (however, it is almost significant at a $10 \%$ significance level (0.103)). Similarly, the impact is negative for IBs post-crisis periods 
(2010-2011), but not significant (0.167). Thus, there is no significant difference in the impact of post-crisis periods between CBs and IBs.

Table 11. Comparison results between the stability of Islamic and conventional banks pre-crisis (2006-2007)

\begin{tabular}{lllllll}
\hline zsc & \multicolumn{5}{l}{ Conventional Banks } & \multicolumn{3}{l}{ Islamic Banks } \\
\hline & Coef. & $\mathrm{z}$ & $\mathrm{P}>\mid \mathrm{z}$ & Coef. & $\mathrm{z}$ & $\mathrm{P}>\mid \mathrm{z}$ \\
\hline gdpg & 0.012602 & 2.07 & $0.039^{* *}$ & 0.0201526 & 1.36 & 0.173 \\
\hline inf & -0.0271674 & -2.97 & 0.003 & 0.0166295 & 0.76 & 0.449 \\
\hline gfcp & -0.0020269 & -0.02 & 0.982 & 0.2051157 & 0.92 & 0.356 \\
\hline opre & -0.0008369 & -0.86 & 0.389 & 0.0019183 & 0.82 & 0.413 \\
\hline hhi & -0.0000983 & -4.61 & $0.000^{*}$ & 0.0000182 & 0.40 & 0.691 \\
\hline fsd & -0.0035743 & -2.21 & $0.027^{* *}$ & 0.0115026 & 2.75 & $0.006^{*}$ \\
\hline liqr & -0.0048236 & -4.02 & $0.000^{*}$ & -0.0088543 & -2.42 & $0.016^{* *}$ \\
\hline car & 0.0091993 & 2.99 & $0.003^{*}$ & 0.0002146 & 0.05 & 0.963 \\
\hline cons & 1.338924 & 9.60 & 0.000 & -0.0147817 & -0.04 & 0.966
\end{tabular}

Note: $* * *, * * *$ Significant at 1,5 and 10 percent levels, respectively

As well as in using before (2000-2006), during (2007-2009) and after crisis (2010-2017) with the whole period as following to Adelopo et al., (2018) and examine the differences in the impact on financial stability of IBs and CBs before, during and after the crisis.

Table 12. Comparison results between the stability of Islamic and conventional banks during crisis (2008-2009)

\begin{tabular}{lllllll}
\hline zsc & \multicolumn{5}{l}{ Conventional Banks } & \multicolumn{3}{l}{ Islamic Banks } \\
\hline & Coef. & $\mathrm{z}$ & $\mathrm{P}>\mid \mathrm{z}$ & Coef. & $\mathrm{z}$ & $\mathrm{P}>\mid \mathrm{z}$ \\
\hline gdpg & 0.0082231 & 1.31 & 0.190 & 0.0159774 & 1.07 & 0.283 \\
\hline inf & -0.0182725 & -2.00 & $0.046^{* *}$ & 0.0384398 & 1.77 & $0.077^{* * *}$ \\
\hline gfcp & -0.2339015 & -2.57 & $0.010^{*}$ & -0.4598228 & -2.13 & $0.033^{* *}$ \\
\hline opre & -0.0005971 & -0.61 & 0.539 & 0.0023028 & 0.98 & 0.325 \\
\hline hhi & -0.0000955 & -4.51 & $0.000^{*}$ & 0.0000171 & 0.38 & 0.706 \\
\hline fsd & -0.0032828 & -2.04 & $0.041^{* *}$ & 0.0119908 & 2.88 & $0.004^{*}$ \\
\hline liqr & -0.004718 & -3.98 & $0.000^{*}$ & -0.0085138 & -2.35 & $0.019^{* *}$ \\
\hline car & 0.0085586 & 2.78 & $0.005^{*}$ & 0.0004724 & 0.10 & 0.917 \\
\hline cons & 1.330844 & 9.58 & 0.000 & -0.0494358 & -0.14 & 0.886
\end{tabular}

Note: $* * *, * * *$ Significant at 1,5 and 10 percent levels, respectively

Also, check changes in the impact of some independent variables on financial stability of CBs and their counterparty of IBs. For the period before the crisis from 2000 to 2006, as shown by Table 14 that the impact of GDP growth is negative for both ZSC_CB and ZSC_IB but not significant. The inflation rate is positively related to both ZSC_CB and ZSC_IB; however, it is significant only for IBs stability at a $10 \%$ level of significance. Inflation rate leads to instability of banks as supposed to be negatively related to bank stability. Even though some researchers have found similar to this study's result, where GDP growth is negatively related to bank stability, and the inflation rate is positively related to bank stability (Ghenimi \& Omri, 2015a; Wassim Rajhi, 2013).

Oil prices risk exposure variable has a negative relationship on stability for all periods, for IBs and CBs, as shown by Tables 14, 15 and 16. Nonetheless, IBs stability has no significant impact on oil price movements for all three periods. However, oil price fluctuations have a significant impact on the stability of CBs for periods before 
(2000-2006) and during (2007-2009) crisis and insignificant impact after the crisis period (2010-2017).

Figure 5 shows the movements of oil prices average over the study period (2000-2017). It increases gradually before the crisis and increases sharply pre-crisis in the year from 2007 to 2008 then suffers a very sharp decline during the crisis, after crisis stars increase again until 2012. The decline after 2012 refers to the political events which happened that time in the Middle East, post which called Arab Spring, as noticed that the decline between 2014 and 2015 was very sharp then get improved again after 2016.

Table 13. Comparison results between stability of Islamic and conventional banks post-crisis (2010-2011)

\begin{tabular}{lllllll}
\hline zsc & \multicolumn{5}{l}{ Islamic Banks } \\
\hline Conventional Banks & Coef. & $\mathrm{z}$ & $\mathrm{P}>\mid \mathrm{z}$ & Coef. & $\mathrm{z}$ & $\mathrm{P}>\mid \mathrm{z}$ \\
\hline inf & 0.0139048 & 2.27 & $0.023^{* *}$ & 0.0247946 & 1.67 & $0.096^{* * *}$ \\
\hline gfcp & -0.0303824 & -3.49 & $0.000^{*}$ & 0.0157242 & 0.74 & 0.462 \\
\hline opre & -0.1449872 & -1.63 & 0.103 & -0.307805 & -1.38 & 0.167 \\
\hline hhi & -0.0002015 & -0.19 & 0.847 & -0.0002015 & -0.19 & 0.847 \\
\hline fsd & -0.0000988 & -4.65 & $0.000^{*}$ & 0.0000145 & 0.32 & 0.749 \\
\hline liqr & -0.0034261 & -2.13 & $0.033^{* *}$ & 0.0114975 & 2.76 & $0.006^{*}$ \\
\hline car & -0.0047942 & -4.04 & $0.000^{*}$ & -0.0088797 & -2.43 & $0.015^{* *}$ \\
\hline cons & 0.0092618 & 3.01 & $0.003^{*}$ & 0.0007102 & 0.16 & 0.876 \\
\hline
\end{tabular}

Note: $* * *, * * *$ Significant at 1,5 and 10 percent levels, respectively

Table 14. Comparison results between the stability of Islamic and conventional banks before crisis (2000-2006)

\begin{tabular}{lllllll}
\hline zsc & \multicolumn{2}{l}{ Conventional Banks } & \multicolumn{3}{l}{ Islamic Banks } \\
\hline & Coef. & $\mathrm{z}$ & $\mathrm{P}>\mid \mathrm{z}$ & Coef. & $\mathrm{z}$ & $\mathrm{P}>\mid \mathrm{z}$ \\
\hline gdpg & -0.009039 & -1.01 & 0.311 & -0.0066078 & -0.23 & 0.819 \\
\hline inf & 0.0115344 & 0.62 & 0.536 & 0.1044832 & 1.69 & $0.090^{* * *}$ \\
\hline opre & -0.0112521 & -3.02 & $0.003^{*}$ & -0.0089329 & -0.72 & 0.470 \\
\hline hhi & -0.0001183 & -5.35 & $0.000^{*}$ & 0.0000314 & 0.50 & 0.618 \\
\hline fsd & 0.009902 & 2.07 & $0.038^{* *}$ & 0.0656152 & 4.28 & $0.000^{*}$ \\
\hline liqr & -0.003112 & -1.91 & $0.056^{* * *}$ & -0.009831 & -1.78 & $0.076^{* * *}$ \\
\hline car & 0.0057758 & 1.67 & $0.095^{* * *}$ & -0.0042313 & -0.61 & 0.540 \\
\hline cons & 1.247194 & 6.01 & 0.000 & -1.666161 & -2.25 & 0.024 \\
\hline Not & $* * *$ Sign & & &
\end{tabular}

Note: $* * *, * * *$ Significant at 1,5 and 10 percent levels, respectively

For the banking industry variables and refer to Tables 14, 15 and 16, HHI has a negative and significant impact on ZSC_CBs for periods before (2000-2006) and during the crisis (2007-2009), while after crisis period (2010-2017) was recorded a positive and insignificant impact. These results, especially negative and significant impact consistent with most studies of stability (Čihák \& Hesse, 2010; Ghassan et al., 2013). However, it is positively related to the stability of IBs before and after the crisis and negatively during the crisis but insignificant impact for all except after crisis, which recorded as a positive and significant impact at 5\% significant level. The result of after crisis for IBs was the opposite of the HHI hypothesis, but it is consistent with study of Srairi (2013), who used concentration ratio to measure banking concentration. However, it is consistent with study of Rajhi and Hassairi (2013), who found a positive relationship between HHI as a measurement of banking concentration and financial stability of large banks in Southeast Asian countries.

Table 15. Comparison results between the stability of Islamic and conventional banks during crisis (2007-2009) 


\begin{tabular}{lllllll}
\hline zsc & \multicolumn{5}{l}{ Conventional Banks } & \multicolumn{2}{l}{ Islamic Banks } \\
\hline & Coef. & $\mathrm{z}$ & $\mathrm{P}>\mid \mathrm{z}$ & Coef. & $\mathrm{z}$ & $\mathrm{P}>\mid \mathrm{z}$ \\
\hline gdpg & 0.0662824 & 2.53 & $0.011^{* *}$ & 0.0294157 & 0.80 & 0.427 \\
\hline inf & 0.0069274 & 0.40 & 0.690 & 0.0262616 & 1.27 & 0.206 \\
\hline opre & -0.0163949 & -2.79 & $0.005^{*}$ & -0.007506 & -0.99 & 0.322 \\
\hline hhi & -0.0004738 & -1.90 & $0.057^{* * *}$ & -0.0001922 & -0.56 & 0.578 \\
\hline fsd & 0.0032001 & 0.53 & 0.593 & -0.0038817 & -0.46 & 0.647 \\
\hline liqr & -0.0017946 & -0.50 & 0.616 & 0.0079876 & 1.57 & 0.116 \\
\hline car & -0.0097374 & -0.95 & 0.340 & -0.004291 & -0.52 & 0.600 \\
\hline cons & 2.432382 & 3.88 & 0.000 & 1.284319 & 1.52 & 0.129 \\
\hline
\end{tabular}

Note: $* * * * * *$ Significant at 1,5 and 10 percent levels, respectively

For the development of the financial sector, the result shows that it has a significant positive relationship related to financial stability of both IBs and CBs before the crisis (2000-2006) at levels $1 \%$ and 5\% significance level, respectively. Then changed to be insignificant during the crisis period for the stability of both IBs and CBs but became negatively related to ZSC_CB. Results that positively related to financial stability supports result of Bongini et al. (2017), and it is opposite from results of Growe et al. (2014). While after crisis period, FSD is negatively related to stability of IBs and CBs, but it is significant at a 5\% level of significance. These results consistent with most studies of FSD, but it is not expected to be a negative and statistically significant impact on ZSC_CB after the crisis period.

Table 16. Comparison results between the stability of Islamic and conventional banks after crisis 2010-2017

\begin{tabular}{lllllll}
\hline zsc & \multicolumn{5}{l}{ Conventional Banks } & \multicolumn{2}{l}{ Islamic Banks } \\
\hline & Coef. & $\mathrm{z}$ & $\mathrm{P}>\mid \mathrm{z}$ & Coef. & $\mathrm{z}$ & $\mathrm{P}>\mid \mathrm{z}$ \\
\hline gdpg & 0.0117296 & 0.88 & 0.381 & -0.0136396 & -0.56 & 0.572 \\
\hline inf & -0.0581804 & -2.21 & $0.027^{* *}$ & 0.030202 & 0.59 & 0.552 \\
\hline opre & -0.0022441 & -1.27 & 0.205 & -0.0038213 & -1.15 & 0.248 \\
\hline hhi & 0.0000218 & 0.34 & 0.731 & 0.0002413 & 2.34 & $0.019^{* *}$ \\
\hline fsd & -0.0071499 & -2.27 & $0.023^{* *}$ & -0.0071173 & -1.16 & 0.245 \\
\hline liqr & -0.0127919 & -5.53 & $0.000^{*}$ & 0.0022966 & 0.34 & 0.735 \\
\hline car & 0.0266654 & 3.69 & $0.000^{*}$ & 0.0073178 & 0.90 & 0.367 \\
\hline cons & 1.462105 & 3.90 & 0.000 & 1.001095 & 1.42 & 0.156 \\
\hline No & & &
\end{tabular}

Note: $* * *, * * *$ Significant at 1,5 and 10 percent levels, respectively

Also, shown by the Tables 12, 13 and 14 that liquidity risk has significantly (at $10 \%$ level of significance) and negatively impact on ZSC_CB and ZSC_IB before the crisis (2000-2006). However, it is not significant for other periods except after the crisis for ZSC_CB. Hence, it is reported in the literature that although IBs withstood and performed better than CBs during the financial crisis, they suffered declining in profitability during 2009 (Hasan \& Dridi, 2011). As it appeares in Figures 2 and 3 for stability and liquidity comparison respectively between IBs and CBs. Thus, it is noticed that IBs performed better during the crisis than CBs as they were more stable and had not lousy liquidity, but the liquidity leaked out during 2009. Thus, IBs reported a decline in liquidity and became less stable than CBs, then suffered losses during 2009.

For the capital ratio of CBs as shown by Tables 14, 15 and 16, it is found that CAR is significant and positively related to ZSC_CB of before and after the crisis but insignificant and negatively related during financial crisis, while CAR of IBs for all periods is insignificant. However, it is reported by many studies that IBs are better capitalized than CBs. That perhaps makes IBs withstood during financial crisis 2008/2009 better than CBs as not a single 
Islamic bank was declared bankrupt, unlike the CBs (Beck, Demirguc-Kunt, \& Merrouche, 2013; Ghassan, Fachin, \& Guendoz, 2013).

As well as Figure 4 clarified the comparison between IBs and CBs in terms of capital. It seems that IBs mostly better capitalized than CBs. However, IBs became less capitalized once they suffered declining in the liquidity and then significant losses in 2009. It is obvious from the Figures 2, 3, 4 and 5 that oil price changes tend to have a positive relationship with stability and capital of IBs and CBs, and a negative relationship with liquidity risk.

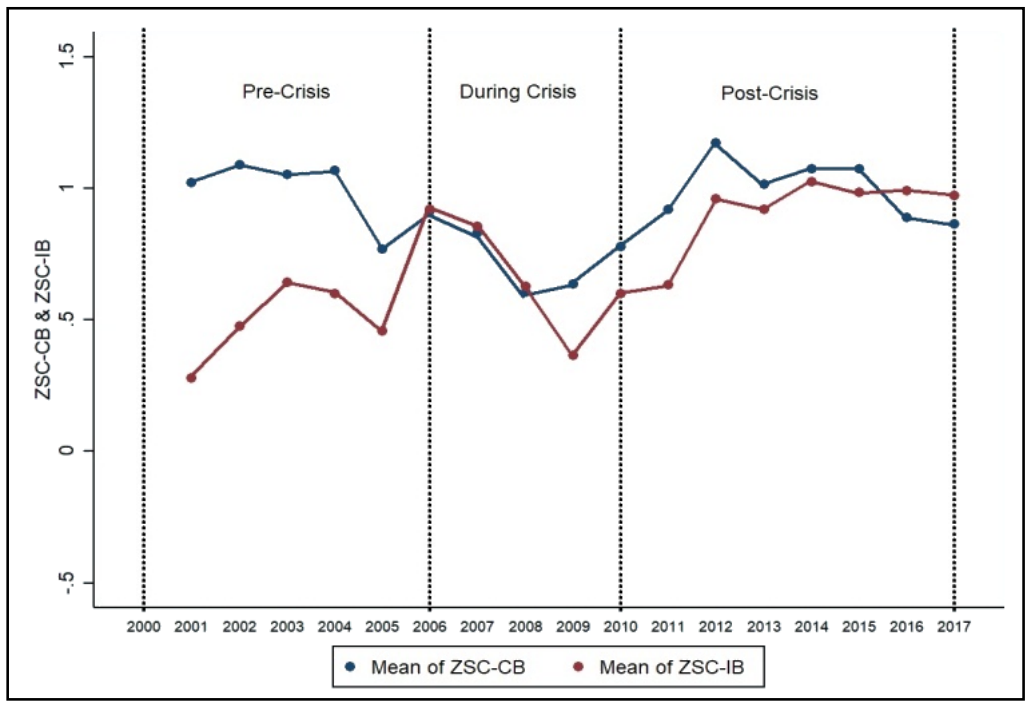

Figure 2. Comparison results between the stability of IBs and CBs before, during and after the crisis

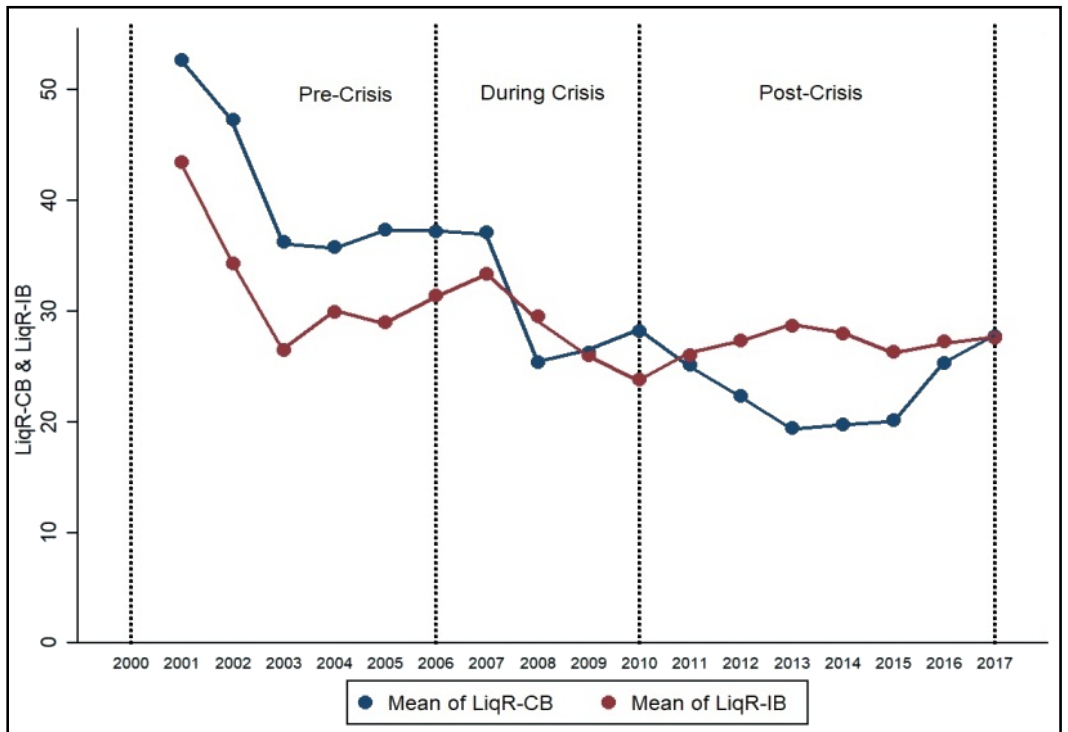

Figure 3. Comparison results between liquidity risk of IBs and CBs before, during and after the crisis 


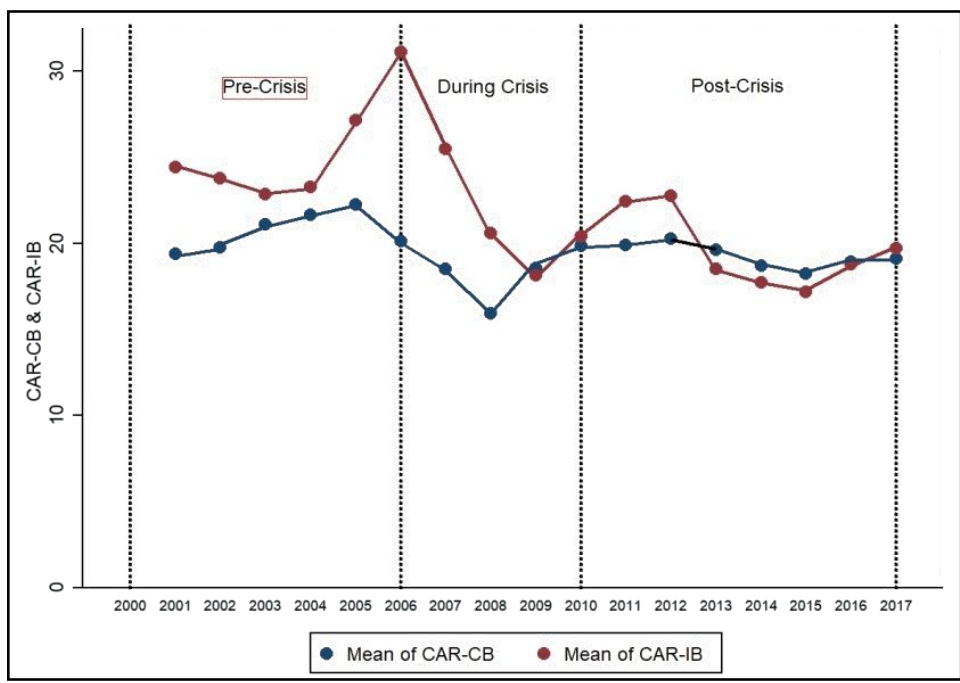

Figure 4. Comparison results between the capital ratio of IBs and CBs before, during and after the crisis

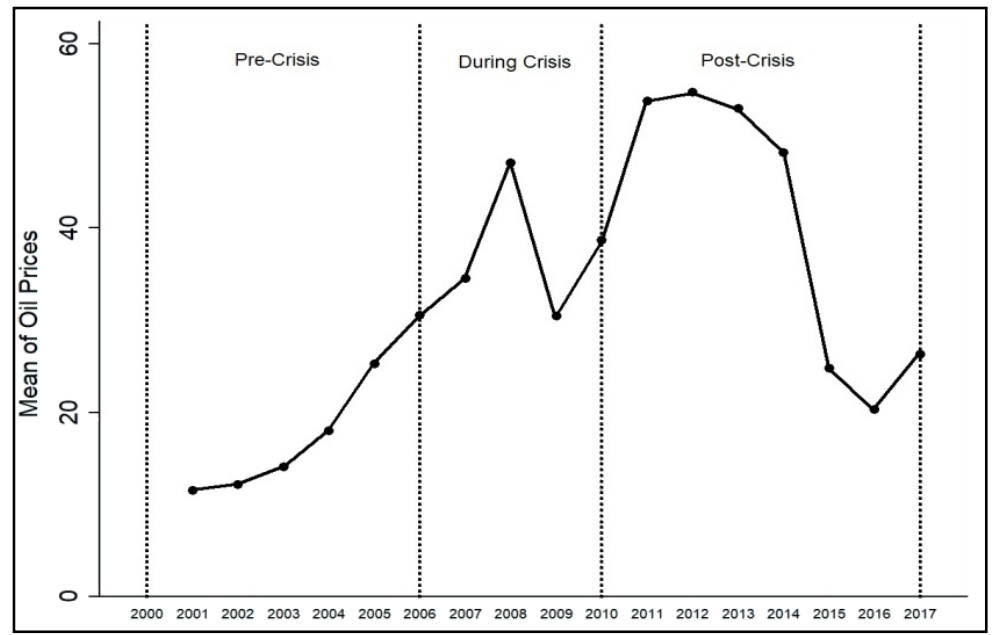

Figure 5. Graphic representation of oil prices before, during and after the crisis.

\section{Discussion and Conclusion}

This study attempts to examine the impact of CAR and liquidity risks on the financial stability of CBs and IBs pre, during and post GFC in the light of many adverse influences of macroeconomic factors in GCC countries such as oil prices decline, GDP growth and inflation rate changes during the period of 2000-2017. Based on the literature, this current study selected three categories, first: macroeconomic variables such as GDP growth, inflation rate, oil prices movement, and GFC periods; pre, during, and post-crisis, which is considered the most related to challenges of GCC economies and influence GCC banks' stability. Second, industry-specific variables which are the development of financial sector and banking concentration and third, bank-specific variables which are CAR and liquidity risks.

This study follows Pedroni's method, which allows for heterogeneity in the coefficients of the cointegration equation, as indicated that the heterogeneity of individual banks may matter more than the nature of the bank, whether Islamic or conventional (Ghassan et al., 2013). The unit root test has found that all variables became stationary at the first difference, that is considered as a prerequisite to use panel cointegration test. Pedroni's panel cointegration test is performed to estimate the long run relationship among the variables. The results of Pedroni's panel cointegration test indicated that the variables are cointegrated, meaning that there is a long run relationship between variables.

Using GLS estimations was because of the presence of heteroskedasticity in the data as well as serial correlation. 
Thus, the study examined the impact of independent variables (GDPG, INF, GFCP, OPRE, FSD, HHI, LIQR, and CAR) on the financial stability of IBs and CBs (ZSC_CB and ZSC_IB). Taking into consideration periods of GFC as pre, during, and post-crisis as well as before, during and after the crisis, under circumstances of sharp declining in oil price, which is considered the leader sector in GCC economies. The study's findings support some previous studies even though this study's methods are mostly different. Thus, it generally concludes that IBs are performed better during the crisis than CBs. Whereas IBs are more stable during crisis as their business model helped to limit the adverse effects of crisis in 2008, they were also more capitalized and less exposure to liquidity risk. Nevertheless, decrease in IBs' liquidity led some IBs in GCC countries to declare a substantial decline in profitability in 2009. Hence, it it referred that this loss was because of the weakness in risk management practices compared to CBs (Hasan \& Dridi, 2011).

The results of the study contribute towards understanding the determinants of financial stability of both IBs and CBs during financial crisis periods. That is important for policy ramifications by the Central Banks in GCC in terms of treating both types of banks differently to mitigate against future financial crises. Future researches should add more relevant variables to this current model and/or use different measures and methodologies. Also, to consider this current model and attempt to examine how to develop banking system performance to be strengthened against the adverse effects of financial crises. Finally, future researches should study more issues about the differentiation between IBs and CBs to contribute to enhancing rules and regulations in this regard.

\section{References}

Abdelbadie, R. A., \& Salama, A. (2019). Corporate governance and financial stability in US banks: Do indirect interlocks matter?. Journal of Business Research, 104, 85-105. https://doi.org/10.1016/j.jbusres.2019.06.047

Abduh, M., Omar, M. A., \& Duasa, J. (2011). The Impact of Crisis and Macroeconomic Variables towards Islamic Banking Deposits. American Journal of Applied Sciences, 8(12), 1378-1383.

Abdul Kader, R., \& Yap, K. L. (2008). The impact of interest rate changes on Islamic bank financing.

Abedifar, P., Molyneux, P., \& Tarazi, A. (2013). Risk in Islamic banking. Review of Finance, 17(6), 2035-2096.

Adebola, S. S., Yusoff, W. S. W., \& Dahalan, J. (2011). The impact of macroeconomic variables on Islamic banks financing in Malaysia. Research Journal of Finance and Accounting, 2(4), 22-32.

Adelopo, I., Lloydking, R., Tauringana, V., \& Lloydking, R. J. C. (2018). Determinants of bank profitability before, during, and after the financial crisis. International Journal of Managerial Finance, 14(4), 378-398. https://doi.org/10.1108/IJMF-07-2017-0148

Adelopo, I., Lloydking, R., Tauringana, V., \& Lloydking, R. J. C. (2018). Determinants of bank profitability before, during, and after the financial crisis. International Journal of Managerial Finance, 14(4), 378-398. https://doi.org/10.1108/IJMF-07-2017-0148

Ali, A. S. (2012). Islamic banking structures: Implications for risk and financial stability. Islamic Economic Studies, 20(2), 141-147.

Al-Khazali, O. M., \& Mirzaei, A. (2017). The impact of oil price movements on bank non-performing loans: Global evidence from oil-exporting countries. Emerging Markets Review, 31(2016), 193-208. https://doi.org/10.1016/j.ememar.2017.05.006

Al-Khouri, R., \& Arouri, H. (2016). The simultaneous estimation of credit growth, valuation, and stability of the Gulf Cooperation Council banking industry. Economic Systems, 40(3), 499-518. https://doi.org/10.1016/j.ecosys.2015.12.005

Allen, F., \& Carletti, E. (2008). The Roles of Banks in Financial Systems.

Allen, W. A., \& Wood, G. (2006). Defining and achieving financial stability. Journal of Financial Stability, 2(2), 152-172. https://doi.org/10.1016/j.jfs.2005.10.001

Alturai, E., \& Ki. (2013, February). Assessing Risk and Profitability of Islamic Banks: A Comparison Between Islamic and Conventional Banks in the Gulf Cooperation Council.

Al-Wesabi, H. A., \& Ahmad, N. H. (2013). Credit risk of Islamic banks in GCC countries.

Annala, C. N., \& Chen, S. (2011). Convergence of state and local fiscal policies: an application of panel unit root tests. Journal of Economics and Economic Education Research, 12(1), 27.

Askari, H., Iqbal, Z., Krichene, N., \& Mirakhor, A. (2010). The Stability of Islamic Finance. https://doi.org/10.1002/9781118390450 
Baltagi, B. H., \& Wu, P. X. (1999). Unequally spaced panel data regressions with AR (1) disturbances. Econometric Theory, 15(6), 814-823.

Basu, R., Prasad, A., \& Rodriguez, S. (2015). Monetary Operations and Islamic Banking in the GCC: Challenges and Options. IMF Working Paper Middle.

Beck, T., Demirguc-Kunt, A., \& Merrouche, O. (2013). Islamic vs. conventional banking: Business model, efficiency and stability. Journal of Banking and Finance, 37(2), 433-447. https://doi.org/10.1016/j.jbankfin.2012.09.016

Ben Ltaifa, N. (2018). How Developed and Inclusive are Financial Systems in the GCC?. Retrieved from www.imf.org

Bicaba, Z., Kapp, D., \& Molteni, F. (2014). Stability periods between financial crises: The role of macroeconomic fundamentals and crises management policies. Economic Modelling, 43(2014), 346-360.

Bongini, P., Iwanicz-Drozdowska, M., Smaga, P., \& Witkowski, B. (2017). Financial development and economic growth: The role of foreign-owned banks in CESEE countries. Sustainability (Switzerland), 9(3), 1-25. https://doi.org/10.3390/su9030335

Bourkhis, K., \& Nabi, M. S. (2013). Islamic and conventional banks' soundness during the 2007-2008 financial crisis. Review of Financial Economics, 22(2), 68-77. https://doi.org/10.1016/j.rfe.2013.01.001

Callen, T., Khandelwal, P., Miyajima, K., \& Santos, A. (2015). Oil Prices, Financial Stability, and the Use of Countercyclical Macroprudential Policies in the GCC. Prepared for the Annual Meeting of Ministers of Finance and Central Bank Governors.

Castro, V. (2013). Macroeconomic determinants of the credit risk in the banking system: The case of the GIPSI. Economic Modelling, 31(1), 672-683. https://doi.org/10.1016/j.econmod.2013.01.027

Chong, B. S., \& Liu, M.-H. (2009). Islamic banking: interest-free or interest-based?. Pacific-Basin Finance Journal, 17(1), 125-144.

Čihák, M., \& Hesse, H. (2008). Islamic Banks and Financial Stability: An Empirical Analysis. International Journal of Business and Commerce, 5(03), 64-87. https://doi.org/10.1007/s10693-010-0089-0

Čihák, M., \& Hesse, H. (2010). Islamic Banks and Financial Stability: An Empirical Analysis. Journal of Financial Services Research, 38(2), 95-113. https://doi.org/10.1007/s10693-010-0089-0

Clark, E., Mare, D. S., \& Radić, N. (2018). Cooperative banks: What do we know about competition and risk preferences?. Journal of International Financial Markets, Institutions and Money, 52, 90-101. https://doi.org/10.1016/j.intfin.2017.09.008

de Mendonça, H. F., \& de Moraes, C. O. (2018). Central bank disclosure as a macroprudential tool for financial stability. Economic Systems, 42(4), 625-636. https://doi.org/10.1016/j.ecosys.2018.07.001

Degl'Innocenti, M., Grant, K., Šević, A., \& Tzeremes, N. G. (2018). Financial stability, competitiveness and banks' innovation capacity: Evidence from the Global Financial Crisis. International Review of Financial Analysis, 59, 35-46. https://doi.org/10.1016/j.irfa.2018.07.009

Distinguin, I., Roulet, C., \& Tarazi, A. (2013). Bank regulatory capital and liquidity: Evidence from US and European publicly traded banks. Journal of Banking and Finance, 37(9), 3295-3317. https://doi.org/10.1016/j.jbankfin.2013.04.027

Fethi, M. D., \& Pasiouras, F. (2010). Assessing bank efficiency and performance with operational research and artificial intelligence techniques: A survey. European Journal of Operational Research, 204(2), 189-198. https://doi.org/10.1016/j.ejor.2009.08.003

Fowowe, B. (2011). The finance-growth nexus in Sub-Saharan Africa: Panel cointegration and causality tests. Journal of International Development, 23(2), 220-239.

Fu, X. (Maggie), Lin, Y. (Rebecca), \& Molyneux, P. (2014). Bank competition and financial stability in Asia Pacific. Journal of Banking and Finance, 38(1), 64-77. https://doi.org/10.1016/j.jbankfin.2013.09.012

Gamaginta, \& Rokhim, R. (2009). The Stability Comparison between Islamic Banks and Conventional Banks: Evidence in Indonesia. 8th International Conference on Islamic Economics and Finance (pp. 1-29).

Ghassan, H. B., \& Fachin, S. (2016). Time series analysis of financial stability of banks: Evidence from Saudi Arabia. Review of Financial Economics, 31, 3-17. https://doi.org/10.1016/j.rfe.2016.06.007

Ghassan, H. B., Fachin, S., \& Guendoz, A. A. (2012). Financial Stability of Islamic and Conventional Banks in 
Saudi Arabia: a Time Series Analysis (pp. 1-21).

Ghenimi, A., \& Omri, M. A. B. (2015a). Liquidity and Financial Stability Conventional versus Islamic Banks. International Journal of Economics and Empirical Research, 3(9), 419-432.

Ghenimi, A., Ali, M., Omri, B., \& Universitaire, C. (2015). Liquidity Risk Management: A Comparative Study between Islamic and Conventional Banks.

Ghosh, S. (2014). Risk, capital and financial crisis: Evidence for GCC banks. Borsa Istanbul Review, 14(3), 145-157. https://doi.org/10.1016/j.bir.2014.06.003

Granger, C. W. (1969). Investigating causal relations by econometric models and cross-spectral methods. Econometrica: Journal of the Econometric Society, 424-438.

Growe, G., DeBruine, M., Lee, J. Y., \& Maldonado, J. F. T. (2014). The Profitability and Performance Measurement of U.S. Regional Banks Using the Predictive Focus of the "Fundamental Analysis Research". Advances in Management Accounting, 24, 189-237. https://doi.org/10.1108/S1474-787120140000024006

Hadri, K. (2000). Testing for stationarity in heterogeneous panel data. The Econometrics Journal, 3(2), 148-161.

Hansen, C. B. (2007). Generalized least squares inference in panel and multilevel models with serial correlation and fixed effects. Journal of Econometrics, 140(2), 670-694.

Hasan, M., \& Dridi, J. (2011). The effects of the global crisis on Islamic and conventional banks: A comparative study. Journal of International Commerce, Economics and Policy, 2(02), 163-200.

Im, K. S., Pesaran, M. H., \& Shin, Y. (1997). Testing for Unit Roots in Heterogeneous Panels. Mimeo, Department of Applied Economics, Universityof Cambridge.

Im, K. S., Pesaran, M. H., \& Shin, Y. (2003). Testing for unit roots in heterogeneous panels. Journal of Econometrics, 115(1), 53-74.

IMF. (2015). Oil Prices, Financial Stability, and the Use of Countercyclical Macro Prudential.

Jackson, J. E. (2003). A User's Guide to Principal Components. New York: Wiley.

Jolliffe, I. T. (2002). Principal Component Analysis (2nd ed.). New York: Springer.

Kammer, M. A., Norat, M. M., Pinon, M. M., Prasad, A., Towe, M. C. M., \& Zeidane, M. Z. (2015). Islamic finance: Opportunities, challenges, and policy options: International Monetary Fund.

Khandelwal, P., Miyajima, M. K., \& Santos, M. A. O. (2016). The impact of oil prices on the banking system in the GCC. International Monetary Fund.

Klingelhöfer, J., \& Sun, R. (2019). Macroprudential policy, central banks and financial stability: Evidence from China. Journal of International Money and Finance, 93, 19-41. https://doi.org/10.1016/j.jimonfin.2018.12.015

Levin, A., \& Lin, C.-F. (1993). Unit root tests in panel data: new results. Economics Working Paper Series, University of California at San Diego.

Levin, A., Lin, C.-F., \& Chu, C.-S. J. (2002). Unit root tests in panel data: asymptotic and finite-sample properties. Journal of Econometrics, 108(1), 1-24.

Mare, D. S., Moreira, F., \& Rossi, R. (2017). Nonstationary Z-Score measures. European Journal of Operational Research, 260(1), 348-358. https://doi.org/10.1016/j.ejor.2016.12.001

Mehrara, M. (2008). The asymmetric relationship between oil revenues and economic activities: The case of oil-exporting countries. Energy Policy, 36(3), 1164-1168. https://doi.org/10.1016/j.enpol.2007.11.004

Miah, M. D., \& Uddin, H. (2017). Efficiency and stability: A comparative study between Islamic and conventional banks in GCC countries. Future Business Journal, 3(2), 172-185. https://doi.org/10.1016/j.fbj.2017.11.001

Miller, S., \& Startz, R. (2018). Feasible Generalized Least Squares Using Machine Learning.

Musibau, H. O., Yusuf, A. H., \& Gold, K. L. (2019). Endogenous specification of foreign capital inflows, human capital development and economic growth: A study of pool mean group. International Journal of Social Economics.

Osborne, M., Fuertes, A.-M., \& Milne, A. (2012). Capital and profitability in banking: Evidence from US banks.

Pedroni, P. (1999). Critical values for cointegration tests in heterogeneous panels with multiple regressors. Oxford Bulletin of Economics and Statistics, 61(S1), 653-670.

Pedroni, P. (2004). Panel cointegration: asymptotic and finite sample properties of pooled time series tests with an 
application to the PPP hypothesis. Econometric Theory, 20(3), 597-625.

Rajhi, W. (2013). Islamic Banks and Financial Stability: A Comparative Empirical Analysis Between MENA and Southeast Asian Countries. Région et Développement, 37, 1-31. https://doi.org/10.2139/ssrn.2010126

Ree, J. J. K. (2011). Impact of the global crisis on banking sector soundness in Asian low-income countries.

Sapuan, N. (2013). A Panel Cointegration Analysis of Bank profitability and Bank-specific Variables in Islamic Banks. Proceedings of 3rd Asia-Pacific Business Research Conference 25-26 February 2013, 8(3/2013), 195-209. Kuala Lumpur, Malaysia.

Shahid, M. A. (2012). Financial stability of Islamic banking in Pakistan: An empirical study. African Journal of Business Management, 6(10), 3706-3714. https://doi.org/10.5897/AJBM11.1306

Shaukat, M., Hasan, Z., \& Alhabshi, D. S. O. (2014). Financing Economic Growth with Stability from Islāmic Perspective. Journal of Islamic Business and Management, 219(2622), 1-48.

Siraj, K. K., \& Pillai, P. S. (2012). Comparative Study on Performance of Islamic Banks and Conventional Banks in GCC region. Journal of Applied Finance \& Banking, 2(3), 123-161.

Srairi, S. (2013). Ownership structure and risk-taking behaviour in conventional and Islamic banks: Evidence for MENA countries. Borsa Istanbul Review, 13(4), 115-127. https://doi.org/10.1016/j.bir.2013.10.010

Sufian, F., \& Habibullah, M. S. (2009). Bank specific and macroeconomic determinants of Profitability of Bangladesh's Commercial Banks. Bangladesh Development Studies, XXXV(4).

Syed Ali, R. (2017). Impact of foreign capital inflows on economic growth in the presence of currency and banking crises. PhD Thesis, Universiti Utara Malaysia.

Toumi, K., Viviani, J.-L., \& Belkacem, L. (2011). A comparison of leverage and profitability between Islamic and conventional banks. 6th International Finance Conference on Financial Crisis and Governance (pp. 768-784).

Wassim Rajhi, S. A. H. (2013). Islamic Banks and Financial Stability: A Comparative Empirical Analysis Between MENA and Southeast Asian Countries. Région et Développement, 37, 1-31. https://doi.org/10.2139/ssrn.2010126

Youssef, A., \& Samir, O. (2015). A Comparative Study on the Financial Performance between Islamic and Conventional Banks: Egypt case. International Journal of Business \& Economic Development, 3(3), 20. https://doi.org/10.3844/ajebasp.2015.106.111

Yuksel, S. (2017). The causality between returns of interest-based banks and Islamic banks: the case of Turkey. International Journal of Islamic and Middle Eastern Finance and Management, 10(4), 519-535.

Yusof, R. M., \& Bahlous, M. (2013). Islamic banking and economic growth in GCC \& East Asia countries: A panel cointegration analysis. Journal of Islamic Accounting and Business Research, 4(2), 151-172.

Zarrouk. (2012). Does Financial Crisis Reduce Islamic Banks' Performance? Evidence from GCC Countries Zarrouk. Journal of Islamic Finance and Business Research, 1(1), 1-16.

\section{Notes}

Note 1. Concentration ratio is the sum of deposits (or assets) for three (some of the studies five) largest banks divided by the deposits (or the total assets) of all banks in the banking system.

Note 2. HHI is the sum of squared market shares of all banks using bank deposits (also, some studies have used bank loans or bank total assets.

Note 3. Panel v-statistic, panel PP-statistic, panel $\rho$-statistic, and panel ADF-statistic.

Note 4. Group $\rho$-statistic, group PP-statistic, and group ADF-statistic. 